The Open Biomarkers Journal
CrossMark
Content list available at: www.benthamopen.com/TOBIOMJ/
DOI: $10.2174 / 1875318301808010009$

REVIEW ARTICLE

\title{
Precision Medicine Approaches to Cancer Diagnosis and Treatment: Focus on Cancer Stem Cell Biomarkers
}

\author{
Katarzyna Rygiel ${ }^{*}$ \\ Department of Environmental Medicine and Epidemiology, Medical University of Silesia (SUM), Zabrze, Poland
}

Received: September 11, 2017

Revised: December 11, 2017

Accepted: January 2, 2018

\begin{abstract}
:
Background:

Recent research evidence has revealed that cancer cells contain a subpopulation of cancer stem cells (CSCs) that can remain even after traditional oncology therapies (e.g.: surgical resection of a tumor, radiation therapy (RT), and chemotherapy (ChT)), and can subsequently regenerate the original tumor or metastases, which are resistant to standard anticancer treatments. Such a resistance can be activated in various CSC populations, via different signal transduction pathways.
\end{abstract}

\section{Conclusion:}

The signaling pathways (e.g.: NANOG, Wnt/ $\beta$-catenin, Hedgehog, Notch, signal transducer and activator of transcription 3 (STAT 3), and phosphoinositide 3-kinase (PI3K)) play a crucial role in the CSCs, leading to tumorigenesis and metastatic spread. Therefore, their detailed analysis, including innovative biomarkers, is necessary to develop the effective, novel therapies that will specifically target CSCs, in patients with aggressive cancers. This review briefly outlines the concept of CSCs, and key components of CSC dysregulation in the signaling pathways. Furthermore, it describes some innovative strategies, such as: Single-Cell Sequencing (SCS), Circulating Tumor Cells (CTCs), Disseminated Tumor Cells (DTCs), cell-free DNA (cfDNA), and circulating tumor DNA (ctDNA) that may have critical importance in the detection, early diagnosis, prognosis and monitoring of patients with various, difficult to treat malignancies (e.g.: breast or gastrointestinal cancers). It also focuses on some barriers to achieving the clinical management goals (for both patients with cancers and the interdisciplinary treatment teams), as well as suggests some solutions, how to overcome them, in personalized oncology approaches.

Keywords: Cancer, Biomarkers, Cancer Stem Cells (CSCs), Circulating Tumor Cells (CTCs), Precision medicine, Disseminated Tumor Cells (DTCs).

\section{INTRODUCTION}

The concept that cancer develops from normal cells via the accumulation of genetic alterations, which activate carcinogenic pathways or inhibit tumor suppressor genes, has been well-known [1]. It has been established that adult stem cells (SCs) can survive in an undifferentiated state for long periods of time, and have the ability to unlimited selfrenewal and differentiation [2]. Furthermore, the evidence exists that the SCs can acquire some carcinogenesis-initiating mutations that alter the genome stability, cellular growth inhibition, normal cell differentiation, proliferative potential, and resistance to apoptosis. Subsequently, these SCs can turn into cancer stem cells (CSCs), leading to genetic changes in clones of cells, or in primary tumors, and metastatic sites [3].

This review addresses key components of CSC dysregulation in the signaling pathways, and focuses on their possible clinical (diagnostic and therapeutic) implications in personalized (precision medicine) oncology approaches.

Also, this article describes some emerging strategies, such as: Single-Cell Sequencing (SCS), Circulating Tumor

\footnotetext{
* Address correspondence to this author at the Department of Environmental Medicine and Epidemiology, Medical University of Silesia (SUM), Zabrze, Poland, Tel: 33814 1426; 692576 729; E-mails: kasiaalpha@yahoo.co.uk; medsrod@sum.edu.pl
} 
Cells (CTCs), Disseminated Tumor Cells (DTCs), cell-free DNA (cfDNA), and circulating tumor DNA (ctDNA) that may have critical importance in the detection, early diagnosis, prognosis and monitoring of patients with various, difficult to treat malignancies (e.g.: breast or gastrointestinal cancers). It also outlines some barriers to achieving the clinical management goals, for both patients with cancers and the interdisciplinary treatment teams, as well as indicates some ways to overcome them.

\section{CANCER STEM CELL (CSC) PATHWAYS: A 'DOUBLE EDGE SWORD'}

It has been determined that the undesirable phenomenon of resistance to conventional anticancer therapies can be activated in various CSC populations, within the same tumor, via different mechanisms [3]. Since the activation of stemness-signaling pathways seems to play a crucial role in these processes, it is essential to analyze them in order to develop the innovative therapies that will specifically target CSCs [3]. It has been determined that a strict regulation of the signaling pathways, such as: NANOG, Wnt/ $\beta$-catenin, Hedgehog, Notch, signal transducer and activator of transcription 3 (STAT 3), and phosphoinositide 3-kinase (PI3K) (Table 1) [4 - 13] is critical for SCs to maintain the ability to self-renewal and differentiation. On the other hand, however, an abnormal inhibition or activation or of these pathways can adversely upregulate cell proliferation [14]. Moreover, some similarities have been found between SCs and cancer cells. For instance, tumors can originate from the transformation of normal SCs, and almost identical signaling pathways can regulate self-renewal in SCs, and in cancer cells. In addition, cancer cells may contain a subpopulation of cancer stem cells (CSCs) that are characterized by the potential for both self-renewal and tumorigenesis [14]. As a consequence, the remaining CSCs even after traditional oncology therapies, such as surgical resection of a tumor, radiation therapy (RT), and chemotherapy (ChT), can regenerate the original tumor, at the primary location, or at the metastatic sites. Since the tumor recurrence originates from the CSCs, which evaded conventional anticancer treatments, such relapsed tumors are usually very aggressive, and resistant to standard anticancer therapies [15].

Table 1. Key components of Cancer Stem Cells (CSCs) dysregulation in the stemness signaling pathways and their possible clinical implications in oncology.

\begin{tabular}{|c|c|c|c|c|}
\hline $\begin{array}{l}\text { Main Signaling } \\
\text { Pathways }\end{array}$ & $\begin{array}{l}\text { Key Physiologic } \\
\text { Functions }\end{array}$ & $\begin{array}{l}\text { Dysregulation in Signaling } \\
\text { Pathways }\end{array}$ & $\begin{array}{l}\text { Role in Cancer } \\
\text { Development }\end{array}$ & $\begin{array}{l}\text { Potential Implications in } \\
\text { Oncology }\end{array}$ \\
\hline $\begin{array}{l}\text { NANOG [4] } \\
\text { a transcription factor }\end{array}$ & \begin{tabular}{|l|} 
a regulator of ESCs \\
self-renewal; \\
an inhibitor of SCs \\
differentiation; \\
a regulator of SCs \\
pluripotency; \\
a regulator of cell-fate \\
specification, \\
proliferation, \\
apoptosis; \\
\end{tabular} & $\begin{array}{l}\text { overexpressed in various cancers } \\
\text { (e.g.: esophagus, colon, ovary, } \\
\text { prostate, breast, \& brain); } \\
\text { overexpression correlated with } \\
\text { advanced stages of malignancy and } \\
\text { poor prognosis. }\end{array}$ & $\begin{array}{l}\text { clonogenic growth, } \\
\text { tumorigenicity, } \\
\text { transformation, invasiveness, } \\
\text { metastasis and therapeutic } \\
\text { resistance; } \\
\text { a part of regulatory network, } \\
\text { communicating with other } \\
\text { transcription factors in cancer } \\
\text { cells }\end{array}$ & $\begin{array}{l}\text { a potential target for oncology } \\
\text { therapy (e.g., gastrointestinal } \\
\text { malignant tumors) }\end{array}$ \\
\hline $\begin{array}{l}\text { Wnt/ } \boldsymbol{\beta} \text {-catenin [5] } \\
\text { a signaling regulatory } \\
\text { network regulated by the } \\
\text { microenvironment }\end{array}$ & $\begin{array}{l}\text { a role in } \\
\text { embryogenesis -the } \\
\text { regulation of apoptosis } \\
\text { in developing cells; } \\
\text { the regulation of tissue } \\
\text { homeostasis and SC } \\
\text { function in adult } \\
\text { tissues; }\end{array}$ & $\begin{array}{l}\text { contributes to inducing epithelial- } \\
\text { to-mesenchymal transition (EMT), } \\
\text { an early step in the invasion- } \\
\text { metastases, relevant to poor clinical } \\
\text { outcomes }\end{array}$ & $\begin{array}{l}\text { aberrant Wnt signaling } \\
\text { regulation in GI cancers }(e . g \text { : } \\
\text { colon, hepatocellular) \&, } \\
\text { medulloblastoma }\end{array}$ & $\begin{array}{l}\text { inhibition of } \mathrm{Wnt} / \beta \text {-catenin } \\
\text { signaling can affect cancer } \\
\text { cell growth and survival }\end{array}$ \\
\hline $\begin{array}{l}\text { Hedgehog }(\mathbf{H H})[6,7, \\
17] \\
\text { a developmental } \\
\text { pathway, which can be } \\
\text { altered by CSCs in } \\
\text { tumorigenesis }\end{array}$ & $\begin{array}{l}\text { a role in cell } \\
\text { differentiation \& } \\
\text { organogenesis during } \\
\text { the embryonic } \\
\text { development; } \\
\text { involved in the } \\
\text { development \& } \\
\text { maintenance of } \\
\text { intestinal tissue; }\end{array}$ & $\begin{array}{l}\text { dysregulated in GI cancers \& in } \\
\text { basal-cell carcinoma. }\end{array}$ & $\begin{array}{l}\text { inhibitors of } \mathrm{HH} \text { signaling are } \\
\text { being explored in clinical } \\
\text { trials for basal-cell carcinoma } \\
\text { \& gastrointestinal cancers }[7, \\
8]\end{array}$ & $\begin{array}{l}\text { Vismodegib [7] small- } \\
\text { molecule inhibitor of the HH } \\
\text { pathway, associated with } \\
\text { tumor responses in patients } \\
\text { with advanced or metastatic } \\
\text { basal-cell carcinoma; HH } \\
\text { inhibition can reverse ChT } \\
\text { resistance in CD44(+) cells; } \\
\text { combining ChT with HH } \\
\text { inhibition may only be } \\
\text { effective in gastric tumors } \\
\text { with high CD44 levels [8] }\end{array}$ \\
\hline
\end{tabular}


(Table 1) contd.....

\begin{tabular}{|c|c|c|c|c|}
\hline $\begin{array}{l}\text { Main Signaling } \\
\text { Pathways }\end{array}$ & $\begin{array}{l}\text { Key Physiologic } \\
\text { Functions }\end{array}$ & $\begin{array}{l}\text { Dysregulation in Signaling } \\
\text { Pathways }\end{array}$ & $\begin{array}{l}\text { Role in Cancer } \\
\text { Development }\end{array}$ & $\begin{array}{l}\text { Potential Implications in } \\
\text { Oncology }\end{array}$ \\
\hline $\begin{array}{l}\text { Notch [9] } \\
\text { the Notch gene encodes } \\
\text { a receptor; } \\
\text { Notch signaling is } \\
\text { crucial in the cell } \\
\text { development by } \\
\text { maintaining the self- } \\
\text { renewal potential of } \\
\text { some tissues \& inducing } \\
\text { cell differentiation of } \\
\text { others }\end{array}$ & \begin{tabular}{|l|} 
signaling between \\
Notch receptors and \\
ligands influences cell \\
differentiation and acts \\
as a tumor suppressor \\
(promoting cell \\
differentiation \& \\
inhibiting \\
proliferation)
\end{tabular} & $\begin{array}{l}\text { in order to cause cancer, Notch } \\
\text { requires the cooperation of } \\
\text { oncoproteins that can override the } \\
\text { G1-S checkpoint. }\end{array}$ & $\begin{array}{l}\text { Notch signaling can promote } \\
\text { or suppress tumor growth, in } \\
\text { communication with other } \\
\text { signal-transduction pathways } \\
\text { (e.g.: Hedgehog, Wnt, or the } \\
\text { factors from tumor micro- } \\
\text { environment) }\end{array}$ & $\begin{array}{l}\text { Notch functions as an } \\
\text { oncogene (e.g., in } \\
\text { hematopoietic cells); } \\
\text { aberrant expression of Notch } \\
\text { can promote T-cell leukemia; }\end{array}$ \\
\hline $\begin{array}{l}\text { STAT3 }[10-12] \\
\text { a specific set of genes, } \\
\text { including those involved } \\
\text { in Jak-STAT signaling } \\
\text { pathway [10] }\end{array}$ & $\begin{array}{l}\text { a latent cytoplasmic } \\
\text { transcription factor, } \\
\text { activated by growth } \\
\text { factors or cytokines; } \\
\text { provides survival } \\
\text { signals \& suppresses } \\
\text { apoptosis }\end{array}$ & $\begin{array}{l}\text { an activator of transcription \& } \\
\text { regulator of cancer cell stemness; } \\
\text { influences cell migration (necessary } \\
\text { for invasion \& metastatic spread); } \\
\text { STAT3 enables CSCs to survive, } \\
\text { proliferate, metastasize, and evade } \\
\text { the immune system; } \\
\text { STAT3 activation protects tumor } \\
\text { cells from immune surveillance \& } \\
\text { augments surviving tumor cells } \\
\text { invading distant organs; } \\
\text { Jak-STAT activation is a } \\
\text { characteristic of putative breast } \\
\text { CSCs }\end{array}$ & $\begin{array}{l}\text { overexpression of STAT3 } \\
\text { leads to development of some } \\
\text { cancers (e.g.: breast, lung, } \\
\text { prostate, colorectal, hepatic, } \\
\& \text { hematological) } \\
\text { Targeting STAT3 activation } \\
\text { can stop tumor growth \& } \\
\text { metastasis, without affecting } \\
\text { normal cells; } \\
\text { STAT3 is an important } \\
\text { molecular target for } \\
\text { anticancer therapies [11] }\end{array}$ & $\begin{array}{l}\text { Napabucasin [12] } \\
\text { a STAT3 inhibitor that can be } \\
\text { a novel treatment strategy for } \\
\text { the advanced prostate cancer } \\
\text { (e.g., castration-resistant } \\
\text { prostate cancer (CRPC) [12] } \\
\text { napabucasin [11] } \\
\text { has been investigated in } \\
\text { colorectal, gastric, } \\
\text { gastroesophageal cancer } \\
\text { (Phase } 3 \text { RCT) }\end{array}$ \\
\hline $\begin{array}{l}\text { PTEN [13] } \\
\text { PI3K/Akt/mTOR a } \\
\text { signaling pathway [13] }\end{array}$ & $\begin{array}{l}\text { PTEN pathway helps } \\
\text { regulate the } \\
\text { proliferative rate \& } \\
\text { number of intestinal } \\
\text { SCs; }\end{array}$ & $\begin{array}{l}\mathrm{PI} 3 \mathrm{~K} / \mathrm{Akt} / \mathrm{mTOR} \text { pathway is a key } \\
\text { regulator for cancer, linked with the } \\
\mathrm{CSCs}\end{array}$ & $\begin{array}{l}\mathrm{PI} 3 \mathrm{~K} / \mathrm{Akt} / \mathrm{mTOR} \text { pathway } \\
\text { can be a promising target for } \\
\text { development of CSC-targeted } \\
\text { agents. }\end{array}$ & $\begin{array}{l}\text { small molecule inhibitors of } \\
\text { PI3K/Akt/mTOR signaling } \\
\text { pathway have clinical } \\
\text { potential in CSCs. }\end{array}$ \\
\hline
\end{tabular}

Abbreviations: ChT, chemotherapy; CRPC, castration-resistant prostate cancer; CSCs, Cancer Stem Cells; EMT, epithelial-to-mesenchymal transition; ESC, embryonic stem cell ; GI, gastrointestinal; HH, Hedgehog; mTOR, mechanistic (mammalian) target of rapamycin; PI3K, phosphoinositide 3-kinase; PTEN, phosphatase and tensin homolog; STAT3, signal transducer and activator of transcription 3; SCs, stem cells

\section{CSC BIOMARKERS: NEW HOPES AND CHALLENGES}

CSCs possess a unique self-renewal activity, together with an ability to mediate tumor initiation and propagation [15]. A process of the identification and isolation of CSCs, using biomarkers (such as cell-surface molecular markers) is a basic step for the development, and subsequent implementation of innovative therapies that can specifically target CSCs. Research in this area has been growing over the last decade. However, many challenges still remain [16]. For instance, several studies were performed on the surface biomarkers for a possible identification and isolation of CSCs. However, lack of universal expression of these surface biomarkers limits their usage. Also, there is no consensus with regard to the most appropriate combination of cell biomarkers for identification of CSCs. In addition, no specific combination of biomarkers has yet been determined to identify the CSCs that can cause initiation and metastatic spread of particular neoplastic tumors. Moreover, many of the presently available biomarkers can also be expressed in nonCSCs [16]. Currently, the most promising biomarker molecules include: CD133, CD44, and the epithelial cell adhesion molecule (EpCAM) (Table 2) [17 - 19].

\section{CLINICAL IMPLICATIONS OF CSC BIOMARKERS: FOCUS ON GASTROINTESTINAL CANCERS}

Gastrointestinal (GI) malignancies represent a group of common cancers, worldwide, often characterized by poor prognosis and high mortality rates [20]. According to the results of recent clinical trials, such as EUROCARE-5, a population-based study, the most common GI cancers, in Europe and in North America, include: colorectal, gastric, and pancreatic cancer. Current therapies of these GI malignancies could be successful, only upon early disease detection (e.g., in localized stages). Otherwise, due to metastasis or relapse, the outcomes of patients with GI cancers are poor. In addition, the recurrent cancer is frequently resistant to conventional ChT or RT, probably due to the CSC properties [21]. In this context, a combination therapy with medications that target CSCs, together with standard anticancer therapy could have a beneficial impact on the outcomes of GI neoplasms. In fact, some investigational agents, for targeting CSCs in GI cancers, are currently in different phases of clinical development. It should be underscored that 
two oral medications: napabucasin and vismodegib have already been approved by the US Food and Drug Administration (FDA) for the therapy of skin basal cell cancer. Recently, these two agents have also been examined in randomized, clinical trials (RCTs) for targeting CSCs, in patients with GI cancers (in which the Hedgehog signaling pathway plays an important role in CD44(+) gastric cancer cells) [22, 23]. Napabucasin is a STAT3 inhibitor, targeting the STAT3, $\beta$-catenin, and NANOG signaling pathways. It inhibits the main genes that are mandatory for maintaining cancer stemness. Napabucasin has revealed antitumor and antimetastatic activity in colorectal, gastric, and gastroesophageal cancer [22]. Vismodegib is an antagonist of the hedgehog pathway, which was studied in a randomized, double-blind, phase 2 clinical trial, in patients with advanced gastric and gastroesophageal junction malignancies, in combination with folinic acid (leucovorin), fluorouracil, and oxaliplatin (FOLFOX) chemotherapy In the vismodegib group, two patients had a complete response, and they revealed enhanced median CD44 expression rates. In contrast, in the chemotherapy-alone group, high CD44 expression was correlated with reduced survival. These findings suggest that the patients who have GI cancers with high CD44 expression can have improved survival upon receiving a combination of FOLFOX chemotherapy and vismodegib [23].

Table 2. The main biomarkers of Cancer Stem Cells (CSCs).

\begin{tabular}{|c|c|c|c|}
\hline Type of Biomarker & Data from Research Studies & Potential Clinical Implications & $\begin{array}{l}\text { Author, Year } \\
\text { Reference }\end{array}$ \\
\hline $\begin{array}{l}\text { CD133 } \\
\text { a marker of cancer stem- } \\
\text { like cells in colorectal } \\
\text { cancer }\end{array}$ & $\begin{array}{l}\text { CD133 is an efficient prognostic factor } \\
\text { in colorectal cancer, according to the } \\
\text { meta-analysis results }\end{array}$ & $\begin{array}{l}\text { higher CD133 expression is correlated with worse disease-free } \\
\text { survival \& overall survival in patients with colorectal cancer; } \\
\text { worse clinical outcome and clinicopathological factors (e.g.: T } \\
\text { category, N category and vascular invasion in patients with } \\
\text { colorectal cancer) have been associated with higher CD133 } \\
\text { expression }\end{array}$ & $\begin{array}{l}\text { Chen S et al. } \\
2013[17]\end{array}$ \\
\hline $\begin{array}{l}\text { CD44 } \\
\text { a hyaluronic acid receptor, } \\
\text { a heat stable antigen, } \\
\text { a surface marker, } \\
\text { expressed by tumor cells }\end{array}$ & $\begin{array}{l}\text { adhesion \& homing of CSCs to the } \\
\text { stem cell niche; } \\
\text { its expression varies at various tumor } \\
\text { stages, and in different types of cancer }\end{array}$ & $\begin{array}{l}\text { the role of CD44 (as CSC surface marker) in tumor initiation, } \\
\text { development, and metastasis has currently been analyzed }\end{array}$ & $\begin{array}{l}\text { Jaggupilli } \\
\text { et al. } \\
2012[18]\end{array}$ \\
\hline $\begin{array}{l}\text { EpCAM (CD326) } \\
\text { (epithelial cell adhesion } \\
\text { molecule) } \\
\text { a glycoprotein, } \\
\text { a marker for carcinoma }\end{array}$ & $\begin{array}{l}\text { cell adhesion, proliferation, migration, } \\
\text { in cancer \& stem cell signaling; } \\
\text { characterized by high expression on } \\
\text { rapidly proliferating tumors from } \\
\text { epithelial tissue; } \\
\text { cell surface expression of EpCAM can } \\
\text { prevent cell-cell adhesion. }\end{array}$ & $\begin{array}{l}\text { EpCAM is not limited only to cell adhesion, but is also involved } \\
\text { in various processes (e.g.: signaling, cell migration, } \\
\text { proliferation, and differentiation); } \\
\text { EpCAM has prognostic relevance in carcinoma, inflammatory } \\
\text { pathophysiology, and tissue development or regeneration, in } \\
\text { addition to its role in epithelial homeostasis. }\end{array}$ & $\begin{array}{l}\text { Trzpis et al. } \\
2007[19]\end{array}$ \\
\hline
\end{tabular}

\section{SINGLE-CELL SEQUENCING (SCS): POSSIBLE ADVANTAGES AND DIFFICULTIES}

In general, malignant carcinomas are characterized by different types of heterogeneity, including: (1) population heterogeneity or differences between tumors from different patients, (2) intratumor or spatial heterogeneity, within a single tumor mass, and (3) temporal heterogeneity reflecting variability over time, during the tumor growth and development, or in response to treatment [24]. In particular, the intratumor heterogeneity (e.g., in breast cancer), is characterized by molecular and genomic variability within carcinomas, and also, among disseminated cells and cell-free nucleic acids. Usually, targeted anticancer treatment agents are designed to focus on actionable mutations that are detected via a biopsy of the primary tumor. However, such "actionable" mutations may no longer cause disease progression, especially when the tumor cells were disseminated from the primary carcinoma and underwent genomic transformation. At this point, the capability of single-cell sequencing (SCS) to reveal the genomic "make-up" of circulating and disseminated cancer cells appears very promising for improving the diagnostic accuracy in patients with cancer. After applying SCS mostly in the research area, there are some potential clinical applications, related to diagnostic work-up, therapeutic decision making, monitoring, and outcome prediction [25]. In fact, the SCS could be particularly useful in an early step of disease diagnosis, via the analysis of blood or urine. During such a noninvasive monitoring of high-risk patients, single disseminated cancer cells or very small tumors can be identified at an early stage, before a malignant lesion can be detected by conventional methods.(e.g., on CT scan). Furthermore, an assessment of genomic heterogeneity within the primary tumor or among disseminated cells would have a prognostic value (e.g., a lower intratumor heterogeneity is usually related with more beneficial outcomes) [24, 26].

SCS may also be used to optimize treatment strategies. For instance, the ability to identify common mutations, throughout a malignant lesion, could permit use of single agent that targets the tumor's bulk, while assaying 
heterogeneous actionable mutations, could lead to implementing novel approaches that simultaneously target sub-clonal populations of cells [25]. For cancer treatment, the most promising clinical use of SCS is the analysis of circulating tumor cells (CTCs), which may provide a non-invasive method for clinicians to monitor individual response to therapy, before tumors become symptomatic or detectable through traditional diagnostic methods. Serial analysis of individual CTCs, isolated from blood samples taken over the course of treatment, may be used to identify new mutations that emerge in response to therapy, which can impact disease progression or therapeutic resistance, enabling oncologists to promptly adjust the treatment, accordingly [27]. In addition, targeted elimination of circulating tumor cells, with stemcell-like expression profiles, could prevent the colonization of secondary sites and formation of metastases [27].

Despite the potential utility of SCS in clinical cancer care, several current limitations need to be addressed before SCS can be used routinely in practice. In the clinical environment, cancerous tissues excised from the body have traditionally been prepared for pathological examination by fixing the tissue in formalin and embedding in paraffin. However, most single-cell isolation and sequencing methods have been designed for use with suspensions of live cells acquired from fresh tissues [28]. Although the nuclear membrane is resistant to freezing and thawing, allowing individual nuclei to be isolated from nuclear suspensions derived from frozen tissues for DNA sequencing fresh tissue is currently needed for single-cell RNA-seq. To implement SCS in the clinic, new tissue collection and handling protocols will have to be established and validated at specialized medical centers and treatment facilities. Single-cell wholegenome amplification (WGA) and whole-transcriptome amplification (WTA) techniques, currently being used, have some technological limitations. A big challenge to implementing SCS in the clinic is overcoming errors that can be introduced by amplifying the minute amount of DNA or RNA in a single cell, and validating the sequencing results [28, 29]. Future improved technologies, as well as new computational methods will be necessary before SCS can reliably distinguish technical errors from true biological variability, and generate valid results to inform the patient care [29]. Currently, the cost of SCS also prohibits its wide implementation in the clinical setting. This is partially due to the fact that many single cells need to be sequenced, depending on a variety of factors (e.g.: the disease stage and tumor heterogeneity), in order to add important medical information to existing baseline. Of course, further large-scale studies, evaluating clinical validity are needed, prior to implementation of SCS into standard diagnostic work-up [30].

\section{CURRENT BARRIERS TO IMPLEMENTING SCS TECHNOLOGY IN THE CLINICAL PRACTICE}

There are some barriers to introducing SCS into the clinical practice, including the cost of SCS, the time necessary for isolation of single cells, DNA amplification, NGS, and data interpretation, and the lack of experts (e.g.: oncologists or pathologists, who will process the sequencing results, and combine them with clinical decision making processes). Some key issues that need to be clarified involve: the interpretation and application of SCS findings in context of individual patients, the translation of DNA or RNA variation within single cells into specific clinical phenotypes, and the methods to use SCS results for prediction of patient response to anticancer therapy [30, 31]. Recently, the Individualized Molecular Pancreatic cancer Therapy (IMPaCT) trial, designed to improve patient outcomes, applying genomic information to direct therapeutic decisions for patients with advanced pancreatic cancer, revealed that a multidisciplinary team (including a pathologist, oncologist, geneticist, genetic counselor, and research coordinator), working in well-equipped setting (e.g., able conduct genomic analyses), and returning the results in an acceptable timeframe (e.g., approximately two weeks) would be required [32]. In the near future, progress in the isolation of single cells, WGA, next-generation sequencing (NGS), and computation methods will be mandatory to improve the clinical utility of SCS. In particular, the ability to amplify and sequence RNA molecules (e.g.: long non-coding RNAs and micro RNAs) can provide important data on gene regulation. Furthermore, innovative methods to amplify and sequence genomic DNA and full-length mRNA, from the same cell, can provide precise tools for evaluating the effects of genomic variation on gene expression profiles [33, 34] Similarly, the ability to couple genome-wide methylation and proteomic analysis, with single-cell DNA- and RNA-sequencing from of individual cells, may reveal some important mechanisms, by which genetic and epigenetic modifications regulate the transcriptional heterogeneity in cancer [35, 36]. Moreover, fluidic systems to simultaneously isolate and analyze millions of cells in parallel can provide a detailed 'portrait' of cancer development and response to therapy, for each individual patient. Finally, localizing the spatial organization of gene and protein expression, within a single cell, can serve as a clue, allowing to determine the behavior and survival of cancer cells during a targeted therapy [37]. Since heterogeneity in patients with malignancies is very dynamic, it can evolve unpredictably during cancer progression, and create many new challenges for anticancer treatments. As a potential solution to these problems, SCS can facilitate precision (personalized) treatment approach, in which the heterogeneity will be well-characterized prior to, and during therapy. In addition, integrated SCS approaches 
can provide new insights into malignancy evolution, and outline new directions for activation of signaling pathways that cause heterogeneous cellular responses to therapy [38].

\section{CIRCULATING TUMOR CELLS (CTCS) AND DISSEMINATED TUMOR CELLS (DTCS)}

It has been known that malignant neoplasms are heterogeneous, and this heterogeneity affects clinical management and patient outcomes (e.g.: recurrence and therapeutic resistance). Consequently, functional significance of the cancer genome of every individual patient is crucial for the development of novel treatments that can overcome difficulties created by molecular heterogeneity [3, 14, 39]. For instance, in breast cancer, intratumor heterogeneity for genetic changes and activated signaling pathways (e.g.: the Notch, Hedgehog, and Wnt) has been noted in populations of putative breast CSCs. This genetic heterogeneity can lead to phenotypic heterogeneity that significantly impacts clinical outcomes, including treatment resistance and metastatic spread [39].

Since rare de novo mutations, and transcriptional changes, in individual cells, usually cannot be detected during assessment of larger parts of the malignant tumors, "single-cell genomics" is being applied to explore individual cells from primary tumors, metastatic lesions, circulating tumor cells (CTCs) or disseminated tumor cells (DTCs), in order to guide subsequent,personalized diagnostic and therapeutic process [40]. It should be highlighted that the cell-free DNA (cfDNA) is composed of nucleic acid parts that have been released to the blood stream from cells during necrosis, apoptosis, or macrophage phagocytosis. The cfDNA can be detected in healthy persons, however, in cancer patients, cfDNA levels in serum are much higher (e.g., especially in patients with metastatic disease) [41]. A fraction of the cfDNA, known as a circulating tumor DNA (ctDNA), is more abundant in the bloodstream than CTCs. Moreover, ctDNA profiles, in patients with metastatic breast cancer, can precisely illustrate the mutations of individual CTCs [41].

\section{CLINICAL IMPLICATIONS OF CTCS FOR THE PATIENT MANAGEMENT}

In clinical practice, a single tumor biopsy is likely to contain only a minority of genetic aberrations present in the entire carcinoma. This often results in underestimation of the mutational burden of heterogeneous tumors, as well as inaccurate prediction of mandatory therapy [42]. For instance, presently, patients with breast cancer rarely undergo a metastatic site biopsy. It should be highlighted that biopsies of metastatic lesions can be clinically required for majority of patients, to make sure that the applied therapies accurately target genomic heterogeneity between the primary carcinoma and metastases [43]. In the future, in order to improve this situation, monitoring of breast cancer heterogeneity (during malignancy progression, or in response to treatment) via CTCs, DTCs, and ctDNA will help overcome sampling bias. Many traditional anticancer medications have been developed to target rapidly proliferating cells of the primary tumor [44]. These agents usually produce clinically beneficial results in initial phases of treatment, illustrated by decreases in size of the primary tumor. However, such a clinical remission is often temporary, since initially quiescent, but genetically diverse CSCs can survive, and lead to recurrence, once a standard therapy is completed. Although the choice of targeted therapy is often based on mutations present in an initial biopsy specimen, these "actionable" mutations may no longer drive cancer progression, when tumor cells disseminate from the primary tumor. Similarly, the predominant clones, in the primary malignant lesion, may not be prevalent in the metastases or CTCs, due to clonal selection that occurs with various therapies. Therefore, it is crucial to identify which clones, within a given cancer patient are the most relevant to cancer progression or treatment resistance [45]. Unquestionably, large clinical trials are needed to assess the value of matching patients to specific, targeted therapies, and to determine whether or not modern genetic profiling could significantly improve patient care [46].

\section{CONCLUSION}

In summary, the discovery of CSCs and related signaling pathways outlined some new research directions in oncology. However, the role of CSC regulatory mechanisms in nonmalignant tissues continues to be a significant challenge to the practical application of CSC-targeted therapies, in patients with different types of malignancies. In the future, the identification and validation of specific biomarkers, which can more accurately detect patients with upregulated CSCs, is one of the priorities. In consequence, an incorporation of such biomarkers into clinical trials, and then, possibly into oncology practice, could help identify patient subpopulations that are most likely to benefit from the combination of standard anticancer treatments (e.g., chemotherapy) and CSC-inhibiting agents. In addition, further understanding of the communication between various CSC signaling pathways is necessary to reveal mechanisms of resistance to therapy. Finally, it should be highlighted that personalized strategies, in which the cancer heterogeneity is precisely characterized (prior to the initiation of therapy) are needed, and deserve exploration, in a large scale clinical trials (investigating the use of different agents targeting CSCs). Subsequent translating of these research findings into 
clinical settings will be useful for guiding precise treatment, in individual patients with the most aggressive malignancies

\section{CONSENT FOR PUBLICATION}

Not applicable.

\section{CONFLICT OF INTEREST}

The author declares no conflict of interest, financial or otherwise.

\section{ACKNOWLEDGEMENTS}

Declared none.

\section{REFERENCES}

[1] Polyak K, Hahn WC. Roots and stems: Stem cells in cancer. Nat Med 2006; 12: 296-300.

[2] Al-Hajj M, Becker MW, Wicha M, Weissman I, Clarke MF. Therapeutic implications of cancer stem cells. Curr Opin Genet Dev 2004; 14: 43-7.

[3] Boman BM, Wicha MS. Cancer stem cells: A step toward the cure. J Clin Oncol 2008; 26: 2795-9.

[4] Sun AX, Liu CJ, Sun ZQ, Wei Z. NANOG: A promising target for digestive malignant tumors. World J Gastroenterol 2014; 20 : 13071-8.

[5] Vermeulen L, De Sousa E, Melo F, et al. Wnt activity defines colon cancer stem cells and is regulated by the microenvironment. Nat Cell Biol 2010; 12: 468-76.

[6] Scales SJ, de Sauvage FJ. Mechanisms of Hedgehog pathway activation in cancer and implications for therapy. Trends Pharmacol Sci 2009; 30: 303-12.

[7] Sekulic A, Migen MR, Oro AE, et al. Efficacy and safety of vismodegib in advanced basal-cell carcinoma. N Engl J Med 2012 ; 366 : 2171-9.

[8] Yoon C, Park DJ, Schmidt B, et al. CD44 expression denotes a subpopulation of gastric cancer cells in which Hedgehog signaling promotes chemotherapy resistance. Clin Cancer Res 2014; 20: 3974-88.

[9] Radtke F, Raj K. The role of Notch in tumorigenesis: Oncogene or tumour suppressor? Nat Rev Cancer 2003 ; 3: 756-67.

[10] Hernandez VH, Ouzounova M, Le CKF, et al. Methylome analysis reveals Jak-STAT pathway deregulation in putative breast cancer stem cells. Epigenetics 2011; 6: 428-39.

[11] Hajimoradi M, Hassan ZM, Ebrahimi M, et al. STAT3 is overactivated in gastric cancer stem-like cells. Cell J 2016; 17: 617-28.

[12] Zhang Y, Jin Z, Zhou H, et al. Suppression of prostate cancer progression by cancer cell stemness inhibitor napabucasin. Cancer Med 2016; 5: 1251-8.

[13] Xia P, Xu XY. PI3K/Akt/mTOR signaling pathway in cancer stem cells: From basic research to clinical application. Am J Cancer Res 2015; 5: 1602-9.

[14] Reya T, Morrison SJ, Clarke MF, Weissman IL. Stem cells, cancer, and cancer stem cells. Nature 2001; 414: $105-11$.

[15] Verga Falzacappa MV, Ronchini C, Reavie LB, Pelicci PG. Regulation of self-renewal in normal and cancer stem cells. FEBS J 2012; 279: 3559-72.

[16] Chen K, Huang YH, Chen JL. Understanding and targeting cancer stem cells: Therapeutic implications and challenges. Acta Pharmacol Sin 2013; 34: 732-40.

[17] Chen S, Song X, Chen Z, et al. CD133 expression and the prognosis of colorectal cancer: A systematic review and meta-analysis. PLoS One 2013; 8: e56380.

[18] Jaggupilli A, Elkord E. Significance of CD44 and CD24 as cancer stem cell markers: An enduring ambiguity. Clin Dev Immunol 2012. 2012: 708036.

[19] Trzpis M, McLaughlin PM, de Leij LM, et al. Epithelial cell adhesion molecule: More than a carcinoma marker and adhesion molecule. Am J Pathol 2007; 171: 386-95.

[20] De Angelis R, Sant M, Coleman MP, et al. Cancer survival in Europe 1999-2007 by country and age: Results of EUROCARE-5--a population-based study. Lancet Oncol 2014; 15: 23-34.

[21] Singh A, Settleman J EMT, et al. Cancer stem cells and drug resistance: An emerging axis of evil in the war on cancer. Oncogene 2010; 29: 4741-51.

[22] Zhang Y, Jin Z, Zhou H, et al. Suppression of prostate cancer progression by cancer cell stemness inhibitor napabucasin. Cancer Med 2016; 5: 1251-8.

[23] Yoon C, Park DJ, Schmidt B, et al. CD44 expression denotes a subpopulation of gastric cancer cells in which Hedgehog signaling promotes chemotherapy resistance. Clin Cancer Res 2014; 20: 3974-88. 
[24] Ellsworth RE, Blackburn HL, Shriver CD, Soon-Shiong P, Ellsworth DL. Molecular heterogeneity in breast cancer: State of the science and implications for patient care. Semin Cell Dev Biol 2017; 64: 65-72.

[25] Navin NE. The first five years of single-cell cancer genomics and beyond. Genome Res 2015; 25: $1499-507$.

[26] Burrell RA, McGranahan N, Bartek J, Swanton C. The causes and consequences of genetic heterogeneity in cancer evolution. Nature 2013; 501: 338-45.

[27] Aparicio S, Caldas C. The implications of clonal genome evolution for cancer medicine. N Engl J Med 2013; $368: 842-51$.

[28] Baslan T, Kendall J, Rodgers L, et al. Genome-wide copy number analysis of single cells. Nat Protoc 2012; 7: 1024-41.

[29] Mato Prado M, Frampton AE, Stebbing J, Krell J. Single-cell sequencing in cancer research. Expert Rev Mol Diagn 2016; 16 : 1-5.

[30] Niu F, Wang DC, Lu J, Wu W, Wang X. Potentials of single-cell biology in identification and validation of disease biomarkers. J Cell Mol Med 2016; 20: 1789-95.

[31] Laskin J, Jones S, Aparicio S, et al. Lessons learned from the application of whole-genome analysis to the treatment of patients with advanced cancers. Cold Spring Harb Mol Case Stud 2015; 1: a000570.

[http://dx.doi.org/10.1101/mcs.a000570]

[32] Chantrill LA, Nagrial AM, Watson C, et al. Precision medicine for advanced pancreas cancer: The individualized molecular pancreatic cancer therapy (IMPaCT) trial. Clin Cancer Res 2015; 21: 2029-37.

[33] Dey SS, Kester L, Spanjaard B, Bienko M, Van OA. Integrated genome and transcriptome sequencing of the same cell. Nat Biotechnol 2015; 33: $285-9$.

[34] Macaulay IC, Teng MJ, Haerty W, Kumar P, Ponting CP, Voet T. Separation and parallel sequencing of the genomes and transcriptomes of single cells using G\&T-seq. Nat Protoc 2016; 11: 2081-103.

[35] Hou Y, Guo H, Cao C, et al. Single-cell triple omics sequencing reveals genetic, epigenetic, and transcriptomic heterogeneity in hepatocellular carcinomas. Cell Res 2016; 26: 304-19.

[36] Darmanis S, Gallant CJ, Marinescu VD, et al. Simultaneous multiplexed measurement of RNA and proteins in single cells. Cell Reports 2016; 14: 380-9.

[37] Lee JH, Daugharthy ER, Scheiman J, et al. Highly multiplexed subcellular RNA sequencing in situ. Science 2014; $343: 1360-3$.

[38] Wang Y, Navin NE. Advances and applications of single-cell sequencing technologies. Mol Cell 2015; 58: 598-609.

[39] Clevers H. The cancer stem cell: Premises, promises and challenges. Nat Med 2011; 17: 313-9.

[40] Zhang X, Marjani SL, Hu Z, Weissman SM, Pan X, Wu S. Single-cell sequencing for precise cancer research: Progress and prospects. Cancer Res 2016; 76: 1305-12.

[41] Shaw JA, Guttery DS, Hills A, et al. Mutation analysis of cell-free DNA and single circulating tumor cells in metastatic breast cancer patients with high CTC counts. Clin Cancer Res 2017; 23: 88-96.

[42] Gerlinger M, Rowan AJ, Horswell S, et al. Intratumor heterogeneity and branched evolution revealed by multiregion sequencing. N Engl J Med 2012; 366: 883-92.

[43] Foukakis T, Åström G, Lindström L, Hatschek T, Bergh J. When to order a biopsy to characterise a metastatic relapse in breast cancer. Ann Oncol 2012; 23(Suppl. 10): x349-53.

[44] Miller SJ, Lavker RM, Sun TT. Interpreting epithelial cancer biology in the context of stem cells: Tumor properties and therapeutic implications 1756.

[45] Aparicio S, Caldas C. The implications of clonal genome evolution for cancer medicine. N Engl J Med 2013; $368: 842-51$.

[46] Bedard PL, Hansen AR, Ratain MJ, Siu LL. Tumour heterogeneity in the clinic. Nature 2013; 501: 355-64.

\section{(C) 2018 Katarzyna Rygiel.}

This is an open access article distributed under the terms of the Creative Commons Attribution 4.0 International Public License (CC-BY 4.0), a copy of which is available at: (https://creativecommons.org/licenses/by/4.0/legalcode). This license permits unrestricted use, distribution, and reproduction in any medium, provided the original author and source are credited. 